\title{
CZY ZNAK TOWAROWY MOŻE BYĆ UTWOREM?*
}

\section{WPROWADZENIE}

Znaki towarowe cieszą się dużą popularnością i są obecne w każdej dziedzinie życia. Są one nośnikiem różnorodnych informacji zarówno o samym towarze lub oferowanej usłudze opatrzonych znakiem, jak i o przedsiębiorcy, który dany towar lub usługę oferuje. Podstawą do przyznania ochrony znakom towarowym jest ich zdolność do przekazywania informacji, które pozwalaja konsumentom na podjęcie świadomego wyboru ${ }^{1}$.

\section{OCHRONA ZNAKÓW TOWAROWYCH W PRAWIE WŁASNOŚCI PRZEMYSŁOWEJ}

Polski system ochrony znaków towarowych został uregulowany w ustawie - Prawo własności przemysłowej². Został on zharmonizowany na mocy Pierwszej dyrektywy Rady z 21 grudnia 1988 r. mającej na celu zbliżenie ustawodawstw państw członkowskich odnoszących się do znaków towarowych (89/104/EWG)3 ${ }^{3}$, która został zastapiona dyrektywą Parlamentu Europejskiego i Rady 2008/95/WE z 22 października 2008 r. mającą na celu zbliżenie ustawodawstw państw członkowskich odnoszących się do znaków towarowych ${ }^{4}$.

Systemy krajowe państw członkowskich UE współistnieją z unijnym systemem ochrony wspólnotowych znaków towarowych. System unijny został ustanowiony rozporządzeniem Rady (WE) nr 40/94 z 20 grudnia 1993 r. w sprawie wspólnotowego znaku towarowego ${ }^{5}$. Rozporządzenie to było nowelizowane i w rezultacie dla zapewnienia jasności i zrozumiałości została sporządzona jego wersja ujednolicona. Obecnie obowiązuje rozporządzenie Rady (WE) nr 207/2009 z 26 lutego 2009 r. w sprawie wspólnotowego znaku towarowego ${ }^{6}$.

\footnotetext{
* Artykuł powstał w ramach projektu badawczego finansowanego ze środków Narodowego Centrum Nauki, przyznanych na podstawie decyzji nr DEC-2012/05/B/HS5/00835.

1 Tak A. Kur, T. Dreier, European Intellectual Property Law. Text, Cases and Materials, Northampton 2013, s. 157.

${ }^{2}$ Ustawa z 30 czerwca 2000 r. - Prawo własności przemysłowej, t.jedn: Dz. U. 2013, poz. 1410 (dalej jako: pr.wł.przem.). Zob. tytuł III, dział I pt. „Znaki towarowe i prawa ochronne”.

${ }^{3}$ Dz. Urz. WE L 40, s. 1; Dz. Urz. UE Polskie wydanie specjalne, rozdz. 17, t. 1, s. 92.

${ }^{4}$ Dz. Urz. UE L 299, s. 25.

${ }^{5}$ Dz. Urz. WE L 11, s. 1; Dz. Urz. UE Polskie wydanie specjalne, rozdz. 17, t. 1, s. 146.

${ }^{6}$ Dz. Urz. UE L 78, s. 1 (dalej jako: rozporządzenie nr 207/2009).
} 
Polscy przedsiębiorcy mogą wybierać krajowy bądź unijny system ochrony znaków. Podstawą przyznania ochrony znaku towarowego będzie jego rejestracja w polskim Urzędzie Patentowym lub w Urzędzie Harmonizacji Rynku Wewnętrznego w Alicante (Office for Harmonization in the Internal Market [Trade marks and designs] - OHIM). Rejestracja jest podstawowym, ale nie jedynym, sposobem ochrony znaków towarowych ${ }^{7}$, gdyż ochrona może przysługiwać także znakom niezarejestrowanym ${ }^{8}$.

Biorąc powyższe pod uwagę, pojawia się pytanie, czy znaki towarowe w tak przyjętym systemie powinny być w ogóle chronione jako utwory (na podstawie przepisów ustawy o prawie autorskim i prawach pokrewnych) ${ }^{9}$. Na gruncie prawa polskiego w literaturze przedmiotu dopuszcza się taką możliwośćc ${ }^{10}$, podobnie orzekają też sądy.

\section{AUTORSKIE PRAWA OSOBISTE I MAJĄTKOWE JAKO PRZESZKODA W REJESTRACJI I UNIEWAŻNIENIE ZNAKU TOWAROWEGO}

\section{Uwagi ogólne}

Prawa autorskie (osobiste i majątkowe) mogą być przeszkodą w rejestracji znaków towarowych, a także podstawą unieważnienia tych już zarejestrowanych.

\section{Rejestracja znaku towarowego}

Zgodnie z art. 131 ust. 1 pkt 1 pr.wł.przem. przeszkodą w rejestracji znaku towarowego mogą być prawa osobiste i majątkowe osób trzecich. Do tych praw osobistych i majątkowych osób trzecich należy zaliczyć także autorskie prawa majątkowe i autorskie prawa osobiste ${ }^{11}$.

${ }^{7}$ Tak R. Skubisz, M. Trzebiatowski, Znaki towarowe $w$ prawie międzynarodowym i prawie Unii Europejskiej, w: System prawa prywatnego, t.14B: Prawo własności przemystowej, red. R. Skubisz, Warszawa 2012, s. 407.

8 J. Kępiński, M. Kępiński, Niezarejestrowane znaki towarowe, w: System prawa prywatnego, t. 15: Prawo konkurencji, red. M. Kępiński, Warszawa 2014, s. 200-215. Zob. też np. wyrok SN z 6 marca 2002 r., V CKN 830/00, Legalis, nr 140387.

${ }^{9}$ Ustawa z 4 lutego 1994 r. o prawie autorskim i prawach pokrewnych, t.jedn.: Dz. U 2006, Nr 90, poz. 631 ze zm. (dalej jako: pr.aut.).

${ }_{10}$ Zob. M. Kępiński, Prawo autorskie a ochrona znaków towarowych. Zagadnienia granic ochrony, w: J. Kępiński, K. Klafkowska-Waśniowska, R. Sikorski (red.), Granice prawa autorskiego. Zarys prawa własności intelektualnej, Warszawa 2010, s. 155-166; M. Trzebiatowski, Autorskoprawny status znaku towarowego (przeglad doktryny), „Monitor Prawniczy” 2011, nr 5, s. 248254; idem, Stowny znak towarowy jako utwór prawnoautorski, „Glosa” 2011, nr 1(146), s. 58-67.

${ }^{11} \mathrm{~W}$ literaturze przedmiotu podkreśla się, że chodzi to przede wszystkim o dobra osobiste wymienione w art. 23 i 24 k.c. Może to być także prawo do wizerunku wskazane w art. 81 pr.aut. Wydaje się też, że może tu chodzić o autorskie prawa osobiste określone w art. 16 pr.aut. Wyobrazić sobie można sytuację, że rejestrowany znak towarowy będzie naruszał prawa osobiste twórcy. W takim przypadku twórca będzie mógł sprzeciwić się rejestracji znaku towarowego. 
W literaturze przedmiotu podnosi się, że zgłoszenie w charakterze znaku towarowego cudzego utworu prawnoautorskiego stanowiłoby niewątpliwie naruszenie autorskich praw majątkowych ${ }^{12}$. Co do zasady okoliczność taka jest przez Urząd Patentowy badana z urzędu, jednakże także osoby trzecie moga, zgodnie z art. 143 pr.wł.przem. ${ }^{13}$, zgłaszać uwagi co do istnienia okoliczności uniemożliwiających udzielenie prawa ochronnego. Tym samym podmiot, któremu przysługują prawa autorskie (majątkowe lub osobiste) do utworu, może skutecznie przeciwstawić się rejestracji znaku towarowego na rzecz innego podmiotu.

\section{Unieważnienie prawa ochronnego}

Z kolei art. 165 pr.wł.przem. reguluje, kiedy nie można wystapić z wnioskiem o unieważnienie prawa ochronnego na znak towarowy. Z interpretacji tego przepisu wynika, że można wystapić z wnioskiem o unieważnienie prawa ochronnego na znak towarowy w przypadku naruszenia praw osobistych lub majątkowych. Nie jest to jednak możliwe, jeżeli przez okres pięciu kolejnych lat używania zarejestrowanego znaku wnioskodawca (tu osoba powołujacy się na swoje prawa autorskie), będąc świadom używania znaku, nie sprzeciwiał się temu. Zatem tolerowanie naruszeń praw autorskich (majątkowych lub osobistych) przez okres pięciu lat będzie prowadzić do utraty możliwości żądania unieważnienia rejestracji ${ }^{14}$. Co do zasady jednak prawa autorskie (zarówno osobiste, jak i majątkowe) mogą być podstawą do unieważnienia prawa ochronnego na znak towarowy ${ }^{15}$.

\section{Unieważnienie w prawie wspólnotowym}

Możliwość unieważnienia prawa ochronnego na znak została także przewidziana w art. 53 ust. 2 lit. c rozporządzenia nr 207/200916. Warto wskazać, że pewne kwestie dotyczące dopuszczalności unieważnienia znaku towarowego

12 R. Skubisz, Prawa osobiste i majatkowe, w: System, t. 14B, s. 749.

13 Art. 143 pr.wł.przem.: „O zgłoszeniu znaku towarowego Urząd Patentowy dokonuje ogłoszenia niezwłocznie po upływie 3 miesięcy od daty dokonania zgłoszenia. Od dnia ogłoszenia osoby trzecie mogą zapoznać się ze wskazanym w zgłoszeniu znakiem towarowym oraz wykazem towarów, dla których znak jest przeznaczony, jak też zgłaszać do Urzędu Patentowego uwagi co do istnienia okoliczności uniemożliwiających udzielenie prawa ochronnego".

14 Tak też. M. Kępiński, Prawo autorskie..., s. 162.

${ }^{15} \mathrm{~W}$ literaturze przedmiotu zauważono też, że z jednej strony jest ugruntowany pogląd, iż uprawniony ze znaku towarowego może występować z roszczeniami z tytułu naruszenia praw autorskich do znaku towarowego, z drugiej - dyskusyjna pozostaje kwestia, czy można przeciwko uprawnionemu ze znaku występować w przypadku, gdy korzystanie ze znaku prowadzi do naruszenia autorskich praw majątkowych. Zob. więcej: J. Barta, R. Markiewicz, Prawo autorskie, Warszawa 2010, s. 408.

${ }^{16}$ Art. 53 ust. 2 rozporządzenia nr 207/2009 stanowi: „Nieważność wspólnotowego znaku towarowego stwierdza się również na podstawie wniosku złożonego do Urzędu lub na podstawie powództwa wzajemnego w postępowaniu w sprawie naruszenia, w przypadku gdy używanie tego znaku towarowego może zostać zabronione z uwagi na inne, wcześniej nabyte prawo na mocy ustawodawstwa wspólnotowego lub prawa krajowego, które zapewniają taką ochronę, w szczególności: a) prawo do nazwy (nazwiska); b) prawo do wizerunku; c) prawo autorskie; d) prawo własności przemysłowej”. 
zostały podniesione w niedawnym wyroku Trybunału Sprawiedliwości Unii Europejskiej (TSUE, Trybunał) dotyczącym wniosku o unieważnienie prawa do wspólnotowego znaku towarowego opartego na prawie autorskim wcześniej nabytym na mocy prawa krajowego ${ }^{17}$.

W rozważanej sprawie OHIM unieważnił rejestrację wspólnotowego znaku towarowego na podstawie wniosku o unieważnienie prawa do znaku „na tej podstawie, iż wnoszacy o unieważnienie prawa do znaku wykazali istnienie prawa autorskiego podlegajacego ochronie na podstawie włoskich przepisów prawnych do znaku niemal identycznego z zakwestionowanym znakiem towarowym oraz fakt, że prawo to jest wcześniejsze niż ten znak towarowy"18. Wzór wspólnotowy i przeciwstawiony mu utwór były następujące.

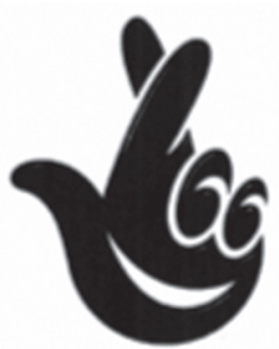

Rysunek 1. Zarejestrowany (kwestionowany) znak wspólnotowy

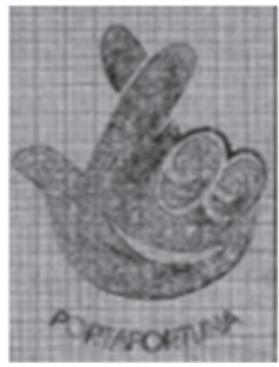

Rysunek 2. Wcześniejszy (przeciwstawiony) utwór

Uprawniony z rejestracji znaku towarowego wniósł odwołanie od tej decyzji i sprawa ostatecznie trafiła do TSUE. I choć Trybunał nie rozstrzygną sprawy, gdyż w postępowaniu przed OHIM dopatrzył się pewnych uchybień formalnych (skutkujących naruszeniem zasady kontradyktoryjności procesu) i przekazał sprawę OHIM do ponownego rozpatrzenia, to warto zwrócić uwagę na argumentację OHIM i Trybunału przedstawiona w uzasadnieniu wyroku, zwłaszcza w kwestiach związanych z podziałem ról między wnoszacym o unieważnienie OHIM i sądem.

Zgodnie $\mathrm{z}$ poglądem wyrażonym $\mathrm{w}$ orzecznictwie i przywołanym przez TSUE: „to na wnioskodawcy ciazzy obowiazek przedstawienia OHIM nie tylko szczegółowych danych wykazujących, że spełnia on przesłanki wymagane zgodnie z ustawodawstwem krajowym, o którego zastosowanie wnosi, aby otrzymać możliwość zakazania używania wspólnotowego znaku towarowego z uwagi na wcześniejsze prawo, lecz również szczegółowych danych określających treść tego ustawodawstwa" ${ }^{19}$.

Z drugiej jednak strony Trybunał uznał za słuszne stanowisko sądu niższej instancji: „w okolicznościach, w których OHIM może zostać wezwany do

\footnotetext{
${ }_{17}$ Wyrok TSUE z 27 marca 2014 r., C 530/12 P, ECLI:EU:C:2014:186.

18 Ibidem, pkt 11.

${ }^{19}$ Ibidem, pkt 34.
} 
wzięcia pod uwagę w szczególności prawa krajowego państwa członkowskiego, gdzie podlega ochronie nabyte wcześniej prawo, na którym oparty jest wniosek o unieważnienie prawa do znaku, OHIM jest obowiązany z urzędu zasięgać informacji dotyczacych prawa krajowego obowiązującego w zainteresowanym państwie członkowskim w sposób, który uzna za właściwy w tym celu, jeżeli informacje takie są niezbędne dla oceny przesłanek stosowania rozpatrywanej podstawy unieważnienia, a w szczególności prawdziwości powoływanych okoliczności faktycznych lub mocy dowodowej przedłożonych dokumentów"

Z powyższego wynika, że to wnioskodawca musi udowodnić, iż w określonym prawie krajowym przysługują mu prawa autorskie do przeciwstawianego zarejestrowanemu znakowi towarowemu utworu. Ponieważ prawo autorskie może różnić się w poszczególnych państwach członkowskich ${ }^{21}$, może się np. okazać, że w niektórych dane dobro materialne będzie można kwalifikować jako utwór, a w innych nie. Wydaje się, że to wnioskodawca będzie musiał przedstawić nie tylko obowiązujace przepisy, lecz także wykładnię tych przepisów przez sądy krajowe. Powstaje natomiast watpliwość, co powinien zrobić wnioskodawca, gdy wykładnia ta jest niejednolita. Czy OHIM ma w takiej sytuacji kompetencje, by rozstrzygać, że dane dobro niematerialne jest utworem, czy nie?

Co więcej, także OHIM jest zobowiązany z urzędu badać prawo krajowe państwa członkowskiego. Nie jest przy tym jasne, w jaki sposób OHIM powinien to uczynić. Sąd uznał, że może „zasięgać informacji w sposób, który uzna za właściwy w tym celu". Nie jest też jasne, w jakim zakresie powinien przeprowadzać badania i kiedy. Sąd uznał, że może to czynić, gdy informacje są „niezbędne”, a badanie powinno w szczególności dotyczyć „prawdziwości powoływanych okoliczności faktycznych lub mocy dowodowej przedłożonych dokumentów”.

Wydaje się, że taka interpretacja przyjęta przez Sąd, a potem powtórzona przez TSUE może budzić liczne kontrowersje i niejasności. Należałoby, jak się wydaje, postulować, by Trybunał znaczenie precyzyjniej określił zadania OHIM, sposób uzyskiwania informacji i ich zakresu.

Ponadto kwestia, która wymagałaby pogłębionej analizy, jest problem, czy Urząd Patentowy i OHIM są organami właściwymi do rozpatrywania sporów dotyczacych praw autorskich. Co do zasady odpowiedź powinna być negatywna. Do rozpatrywania takich sporów bardziej odpowiednia jest droga postępowania cywilnego. Urzędy dokonujące rejestracji byłyby wtedy związane rozstrzygnięciem sądu wydanym po przeprowadzeniu całego postępowania dowodowego. Gdyby strona podnoszaca zarzuty naruszenia przysługujacych jej praw autorskich nie podjęła się ich ochrony na drodze sądowej, ponosiłaby negatywne konsekwencje polegające na rejestracji znaku na rzecz składajacego zgłoszenie o rejestrację znaku towarowego ${ }^{22}$.

20 Ibidem, pkt 45.

${ }^{21}$ Co do zasady nie istnieje wspólne prawo autorskie Unii Europejskiej, aczkolwiek niektóre jego sfery zostały ujednolicone w dyrektywach, zob. J. Barta, R. Markiewicz, op. cit., s. 379-396.

${ }^{22}$ Zob. też M. Kępiński, Prawo autorskie..., s. 162-163. 


\section{UTWORY DAJĄCE SIE ZAKWALIFIKOWAĆ JAKO ZNAK TOWAROWY}

Źródła ochrony prawnoautorskiej należy szukać w art. 1 ust. 1 pr.aut., który stanowi, że „przedmiotem prawa autorskiego jest każdy przejaw działalności twórczej o indywidualnym charakterze, ustalony w jakiejkolwiek postaci, niezależnie od wartości, przeznaczenia i sposobu wyrażenia (utwór)”. Mimo tak szerokiej definicji „utworu” nie wszystkie znaki towarowe będzie można kwalifikować jako utwór. Taka sytuacja będzie miał miejsce w przypadku, gdy znak towarowy nie będzie spełniał ustawowych przesłanek wynikających z pr.aut. (oryginalność i indywidualny charakter).

Nie oznacza to jednak, że dla utworów przeznaczonych do oznaczania towarów i usług można wprowadzać surowsze kryteria przyznania ochrony prawnoautorskiej niż dla innego rodzaju utworów ${ }^{23}$. Nie ma ku temu żadnych podstaw w pr.aut., a samo przeznaczenie utworu nie może mieć wpływu na przyznanie takiej ochrony. Potwierdzenie takie znajduje się w sformułowaniu wskazywanego powyżej art. 1 ust. 1 pr.aut., z którego jasno wynika, że dobro niematerialne może być kwalifikowane jako utwór niezależnie od jego przeznaczenia.

Nie każdy też utwór będzie mógł być znakiem towarowym. Podstawowa bowiem funkcją znaku towarowego jest funkcja oznaczenia pochodzenia, która określa, że znak towarowy musi być zdolny do odróżniania towarów i usług jednego przedsiębiorcy od towarów i usług innego przedsiębiorcy ${ }^{24}$. Jeśli więc utwór nie będzie posiadał zdolności odróżniającej, to nie będzie mógł być znakiem towarowym.

Można wskazać za Marianem Kępińskim ${ }^{25}$, że przy ocenie, jakiego rodzaju utwory mogłyby być znakiem towarowym, należy wziąć pod uwagę:

a) utwory wyrażone słowem (art. 1 ust. 2 pkt 1 pr.aut.). Przykładami takich utworów mogą być znaki towarowe słowne składające się z jednego lub kilku wyrazów, a także slogany reklamowe ${ }^{26}$, czyli dłuższe frazy składające się z kilku wyrazów. Jako przykład można wskazać znaki towarowe zarejestrowane w Urzędzie Patentowym, np. znak słowny „FORD” (zarejestrowany w Urzędzie Patentowym - nr prawa wyłącznego 121943), znak słowny „COCA COLA LIFE, TASTES GOOD" (zarejestrowany w Urzędzie Patentowym - nr prawa wyłącznego 161377), czy też znak słowny „tniemy ceny na długo” (słowny znak towarowy - nr prawa wyłącznego 213825). Choć teoretycznie możliwe jest zakwalifikowanie tego rodzaju znaków towarowych jako utworów, to co do zasady nie będzie przysługiwała im ochrona prawnoautorska. Wyłaczenia takiego nie ma w żadnej z ustaw (pr.aut. i pr.wł.przem.), ale jest ono konsekwencją wykładni przepisów przez sądy (zob. orzeczenia sądów omawiane poniżej).

23 Tak ibidem, s. 158 .

${ }^{24}$ Więcej zob. R. Skubisz, Funkcje znaku towarowego, w: Księga pamiatkowa z okazji 80-lecia rzecznictwa patentowego w Polsce, Warszawa 2001, s. 167-170; M. Kępiński, Rozporzqdzanie prawem z rejestracji znaku towarowego, Poznań 1979, s. 54-55.

${ }_{25}$ M. Kępiński, Prawo autorskie..., s. 158-161.

${ }^{26}$ Zob. więcej K. Grzybczyk, Ochrona sloganu, „Przegląd Prawa Handlowego” 1997, nr 6(57), s. 26-29. 
b) utwory w postaci znaków graficznych i utwory słowno-graficzne (art. 1 ust. 2 pkt 1 pr.aut.). Wydaje się, że tego rodzaju znaki towarowe są najczęściej zgłaszane do rejestracji i są bardzo często używane w obrocie. Jako przykład można wskazać znak słowno-graficzny „Coca Cola” (zarejestrowany w Urzędzie Patentowym - nr prawa wyłącznego 84371) czy znak graficzny firmy Puma (zarejestrowany w Urzędzie Patentowym - nr prawa wyłącznego 60167). Nie ma w zasadzie problemów, by tego rodzaju znaki towarowe mogły być także kwalifikowane jako utwór (zob. omawiane poniżej orzeczenia dotyczące znaku słowno-graficznego: NEW MAN i Pyramid).

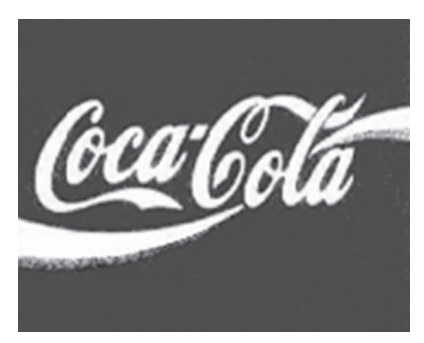

Rysunek 3. Przykład słowno-graficznego znaku towarowego

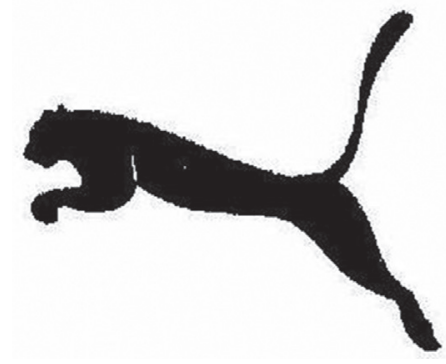

Rysunek 4. Przykład graficznego znaku towarowego

c) utwory plastyczne (art. 1 ust. 2 pkt 2 pr.aut.). Jako znaki towarowe mogą być rejestrowane różnego rodzaju rysunki, obrazy, desenie bądź modele, które mogą być utworami. Jeśli tylko mają one zdolność odróżniająca, moga one być znakami towarowymi. Nie ulega wątpliwości, że mogą być one także utworami.

d) utwory wzornictwa przemysłowego (art. 1 ust. 2 pkt 5 pr.aut.). W przypadku tego rodzaju utworów może chodzić o przestrzenne znaki towarowe, czyli znaki dotyczące kształtu lub opakowania towarów. Jako przykład

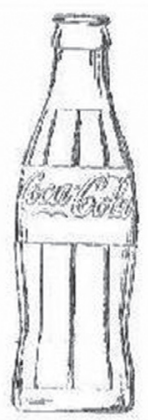

Rysunek 5. Przykład przestrzennego znaku towarowego powszechnie znanego znaku towarowego dotyczącego kształtu towaru można wskazać butelkę Coca-Coli zarejestrowaną w Urzędzie Patentowym (znak zarejestrowany w Urzędzie Patentowym - numer prawa wyłącznego 43544), którą zapewne można by także uznać za utwór.

e) utwory muzyczne (art. 1 ust. 2 pkt 7 pr.aut.). Prawo własności przemysłowej (art. 120) wymaga, by znak towarowy nadawał się do przedstawienia go w formie graficznej. Wymóg ten eliminuje możliwość rejestracji pewnych znaków towarowych (np. znaków zapachowych czy dotykowych). W przypadku znaków towarowych dźwiękowych wymóg graficznej przedstawialności spełniony będzie przez zapis danej melodii czy dźwięków za pomocą nut. W bazie Urzędu Patentowego można znaleźć też takie znaki towarowe (np. znak towarowy zarejestrowany w Urzędzie Patentowym - nr prawa wyłącznego 222433). 
Wyjaśnić należy, że nie zawsze można określony znak towarowy zakwalifikować tylko i wyłącznie do jednej z kategorii utworów. Niektóre znaki towarowe można bowiem uznać np. zarówno za utwór graficzny, jak i utwór plastyczny, czy też utwór plastyczny i utwór wzornictwa przemysłowego.

Zatem w świetle powyższych rozważań wydaje się, że najwięcej wątpliwości może dotyczyć znaków towarowych słownych i słowno-graficznych i te właśnie znaki będą przedmiotem dalszej analizy. Wydaje się, że w przypadku pozostałych wzorów ochrona prawnoautorska, jeśli oczywiście dany znak towarowy spełnia przesłanki wymagane przez pr.aut., jest możliwa i w pełni dopuszczalna ${ }^{27}$.

Nadmienić można, że kumulacja ochrony nie jest w przypadku znaków towarowych w żaden sposób ograniczona przez przepisy pr.aut. i pr.wł.przem. Nie ma bowiem, jak to jest w np. w przypadku wzorów przemysłowych, odpowiednika art. 116 pr.wł.przem..$^{28}$, który jest próbą uregulowania stosunku prawa z rejestracji wzoru przemysłowego do praw autorskich.

\section{UTWORY SŁOWNE I SŁOWNO-GRAFICZNE W ORZECZNICTWIE SĄDÓW POLSKICH}

\section{Utwory słowne (jedno- i wielowyrazowe)}

Słowny znak towarowy to przede wszystkim znak w postaci wyrazu lub kilku wyrazów zestawionych razem.

\subsection{Utwory jednowyrazowe}

Wyrok Sądu Najwyższego z 22 czerwca 2010 r. dotyczył towarowego znaku słownego „JOGI”29. Ze stanu faktycznego sprawy wynika, że powódka (spółka z o.o.) wykonała na zamówienie pozwanego (osoby fizycznej) projekt

\footnotetext{
${ }^{27}$ Zob. M. Trzebiatowski, op. cit., s. 248-249 i wskazywana tam literatura i orzecznictwo.

${ }^{28}$ Art. 116 pr.wł.przem. „Ochrona praw majątkowych do utworu, przewidziana w przepisach prawa autorskiego, nie ma zastosowania do wytworów wytworzonych według wzoru przemysłowego i wprowadzonych do obrotu po wygaśnięciu prawa z rejestracji udzielonego na taki wzór". $\mathrm{Na}$ marginesie można wspomnieć, że pojawiają się wątpliwości, czy art. 116 pr.wł.przem. nie jest sprzeczny z dyrektywą 98/71/WE. Więcej np. J. Kępiński, Wyłqczenie ochrony prawnoautorskiej dla wzorów przemystowych - glosa do wyroku TS z 27.1.2011 r. w sprawie C-168/09, „Europejski Przegląd Sądowy" 2012, nr 4(79), s. 40-46 i wskazywana tam literatura.

${ }^{29}$ Wyrok SN z 22 czerwca 2010 r., IV CSK 359/09, OSNC 2011, nr 2, poz. 16, s. 32; Legalis, nr 237030 wraz z glosa M. Trzebiatowskiego, Stowny znak towarowy jako utwór prawnoautorski, „Glosa” 2011, nr 1(146), s. 58-67; D. Sokołowska, Ochrona stowa w prawie autorskim. Glosa do wyroku SN z 22.06.2010 r. (IV CSK 359/09), „Zeszyty Naukowe Uniwersytetu Jagiellońskiego. Prace z Prawa Własności Intelektualnej” 2011, z. 112, s. 5-8.
} 
etykiet termokurczliwych na opakowania jogurtów oraz zleciła osobie trzeciej opracowanie znaku słowno-graficznego „JOGI”. W tym celu powódka zawarła z tą osobą umowę przeniesienia autorskich praw majątkowych do zaprojektowanego znaku. Zamawiajacy zaczął używać zamówionego znaku i zgłosił w Urzędzie Patentowym do rejestracji znak „JOGI”, lecz prawa z rejestracji nie uzyskał. Wobec powyższego powódka (czyli wykonawca) wniosła do sądu powództwo przeciwko zamawiającemu o zaniechanie naruszania przysługujacych jej autorskich prawa majątkowych m.in. do słownego znaku towarowego „JOGI”. Sąd zarówno pierwszej, jak i drugiej instancji uznały, że pozwany dopuścił się naruszenia autorskich prawa majątkowych przysługujacych powódce.

Orzeczenie to stało się podstawą kolejnych roszczeń powódki. Na jego podstawie powódka wniosła kolejne powództwo przeciwko temu samemu pozwanemu (zamawiającemu), żądajac wynagrodzenia za zawinione naruszenie autorskich prawa majatkowych do utworu - słownego znaku towarowego „JOGI” ${ }^{30}$. W tym stanie rzeczy sąd apelacyjny orzekły, że znak słowny „JOGI” nie jest utworem w rozumieniu pr.aut. i powództwo należało oddalić.

Skargę kasacyjną wniosła powódka, podnosząc m.in. argumenty, że sąd apelacyjny błędnie przyjął, iż słowny znak towarowy „JOGI” nie jest utworem. Sąd Najwyższy oddalił skargę kasacyjna, gdyż uznał, że „[w]yraz »JOGI“ nie wykazuje oryginalności mogacej uzasadniać uznanie go za wyjątek od powszechnie akceptowanej zasady, że pojedyncze słowa nie mają cech twórczości. Nie posiada ono autonomicznych cech utworu i nie staje się utworem z powodu "wymyślenia» sposobu konkretnego jego wykorzystania jako znaku towarowego, czyli do oznaczania towarów określonego rodzaju, pochodzących od określonego przedsiębiorcy”.

Powyższe orzeczenie SN zasługuje na aprobate $e^{31}$, słusznie bowiem uzasadnia, że „użycie słowa jako znaku towarowego nie wpływa na możliwość uznania go za utwór, gdyż istnienie utworu nie może być uwarunkowane określonym jego przeznaczeniem. Sposób korzystania z dzieła nie decyduje o uzyskaniu przez nie statusu utworu”. Tym samym SN nie wyklucza możliwości ochrony prawnoautorskiej jednowyrazowych znaków towarowych z samego tylko faktu, że są używane jako znaki towarowe.

Co do zasady SN jednak stoi na stanowisku, że ochrona prawnoautorska pojedynczych słów, także nieznanych czy neologizmów, powinna być wykluczona, gdyż nie posiadają one najczęściej cechy twórczości. Ewentualnie - zdaniem SN - ochrona prawnoautorska może być przyznana pojedynyczym słowom, ale tylko w sytuacji, gdy będą one cieszyć się zaskakująca „wyrazistością

${ }^{30} \mathrm{Z}$ tego względu wyrok w sprawie JOGI jest często cytowany przez SN w kontekście mocy prawomocnego wyroku (prawomocność materialna), który to aspekt w niniejszym opracowaniu został pominięty. Sąd apelacyjny w sprawie uznał, że „ocenił, że moc wiążąca prawomocnego wyroku [...] wydanego w sprawie pomiędzy powódką a osobą trzecia, nie rozciaga się na ustalenie, że oznaczenie »Jogi“ jest utworem w rozumieniu tej ustawy”.

31 Tak też M. Trzebiatowski, Stowny znak towarowy..., s. 62. 
i błyskotliwościa, współtworza poetykę utworu, stanowią "klucz« do rozumienia utworu".

Podsumowując, można stwierdzić, że „utworom” słownym jednowyrazowym nie przyznaje się w zasadzie ochrony prawnoautorskiej. Od tej reguły mogą być jednak wyjątki, ale w takim przypadku taki wyraz - utwór musi być szczególnie wyrazisty bądź błyskotliwy.

\subsection{Utwory wielowyrazowe}

Podobne rozstrzygnięcia jak w orzeczeniu w sprawie „JOGI” zapadły w także w sprawach dotyczących dłuższych jednostek słownych - sloganów reklamowych. Mimo że orzeczenia te nie dotyczyły sensu stricto sporów z zakresu znaków towarowych, stanowią one dobry przykład, czy zdaniem sądów dłuższe utwory słowne, tj. składające się z więcej niż jednego wyrazu, mogą być kwalifikowane jako utwór. Nie ulega wątpliwości, że takie dłuższe wyrażenie mogłyby być także rejestrowane jako znaki towarowe.

Pierwszy z wyroków (SN z 4 marca $2002 \mathrm{r}^{32}$ ) dotyczył wykorzystania w reklamie margaryny wyrażenia „Serce jak dzwon”. Powodowie domagali się zakazania pozwanym używania go w reklamie, twierdząc, że to oni są twórcami wcześniejszej reklamy (utworu audiowizualnego), w której wykorzystano slogan reklamowy „Serce jak dzwon”. Tym samym przysługują im prawa autorskie do tego wyrażenia.

Sąd Najwyższy uznał, że mimo iż reklamie audiowizualnej (utworowi audiowizualnemu) przysługuje ochrona prawonautorska jako całości, to nie wszystkie jej elementy są objęte ochroną. Sąd stwierdził, że wyrażenie „Serce jak dzwon" nie jest utworem, gdyż nie spełnia kryterium oryginalności. Z tego samego względu nie można uznać go też za slogan reklamowy. Zdaniem SN jest to: „powszechnie znane powiedzenie »o sercu zdrowym bijacym regularnie«. Powiedzenia zaś, podobnie jak słowa, idiomy, czy przysłowia należą do domeny publicznej i każdy ma prawo do korzystania z nich".

Drugi z wyroków (SA w Krakowie z 5 marca 2004 r.) ${ }^{33}$ dotyczył wykorzystania w kampanii reklamowej słów „Ciemność widzę. Oj. Widzę ciemność”. Słowa te były fragmentem dialogu z filmu Seksmisja, których autorem był powód. W związku z wykorzystaniem tego wyrażenia bez jego zgody w kampanii reklamowej, powód wystapił z powództwem o naruszenie praw autorskich do utworu i popełnienia deliktów nieuczciwej konkurencji. Sąd pierwszej instancji powództwo oddalił, uznając, że: „przedmiotowy ciag słów nie stanowi tak dalece twórczej części jego utworów, aby podlegał ochronie, a jeśli nawet stanowi, to powód nie jest autorem tego zestawienia, albowiem doszło już do wcześniejszego użycia go w literaturze".

${ }^{32}$ Wyrok SN z 4 marca 2002 r., V CKN 750/00, Legalis, nr 140386.

${ }^{33}$ Wyrok SA w Krakowie z 5 marca 2004 r., I ACa 35/04, OSA 2004, nr 10, poz. 33, s. 45, Legalis, nr 65550. 
W wyniku wniesionej apelacji Sąd Apelacyjny w Krakowie rozstrzygną sprawę i zgodził się ze stanowiskiem sądu okręgowego, orzekającego w I instancji ${ }^{34}$. Uznał, że: „efekt twórczości (np. scenariusz czy wyreżyserowana wypowiedź aktora) zredukowany do krótkiej figury retorycznej jest na tyle ogólny, że posiada wartość idei. Jako taki, o walorze abstrakcyjnym i ogólnym nie stanowi przedmiotu prawa autorskiego, gdyż traci cechę oryginalności”. Sąd Apelacyjny uznał też, że niezbędne jest podwyższenie progu twórczości dla „krótkich fragmentów cudzego utworu” i wyłączenie ich spod ochrony prawnoautorskiej. Zdaniem Sądu: „nie tylko bowiem świadoma parafraza, lecz nadto wysokie prawdopodobieństwo nieświadomego posługiwania się taką fraza w innych dziełach (w dobie kultury tzw. »obrazkowej« także wypowiadanych przez anonimowych bohaterów), czyni usprawiedliwionym ograniczenie zakresu działania przepisów prawa autorskiego".

W najnowszym wyroku z 16 kwietnia 2013 r. ${ }^{35}$ Sąd Apelacyjny w Warszawie zajął podobne stanowisko jak sądy we wcześniejszych sporach. W sprawie tej autorzy scenariusza do serialu filmowego Czterdziestolatek domagali się ochrony autorskich i osobistych praw majątkowych. Ich zdaniem bowiem zostały one naruszone m.in. poprzez wykorzystanie w reklamie motywu „kobiety pracującej” i używanych w filmie zwrotów ,jestem kobieta pracująca”, „to pani?”. Sąd Okręgowy powództwo oddalił. Apelację wnieśli powodowie.

Są Apelacyjny w Warszawie orzekł, że: „zwroty użyte w filmach reklamowych »jestem kobieta pracująca« i »to pani?«, nie mają autonomicznej wartości twórczej. Banalny i prosty zwrot językowy stanowiący fragment cudzego utworu nie będący w spornym utworze reklamowym cytatem ani zapożyczeniem, co najwyżej inspiracją i odwołaniem do odległych skojarzeń, nie uzasadnia przyjęcia naruszenia praw autorskich”. Sąd uznał też, że nazwa „kobieta pracująca" nie jest nazwą oryginalną i powtórzył argumentację SN w sprawie JOGI. Zdaniem Sądu Apelacyjnego w Warszawie określenie „kobieta pracująca” było używane „w przestrzeni publicznej już w latach pięćdziesiątych, w związku z aktywizacja kobiet na rynku pracy. Sytuacja taka nadal ma miejsce i nie sposób przyjaćc, aby jedynym desygnatem tego pojęcia była postać fikcyjna ze scenariusza do filmu".

Zatem w świetle powyższych orzeczeń wydaje się, że w przypadku wyrażeń składających się z większej ilości wyrazów w zasadzie nie powinno przyznawać się ochrony prawnoautorskiej. Ochrona ta nie jest wykluczona, ale chroniona/potencjalna fraza powinna także cechować się odpowiednią oryginalnością. Proste wyrażenie, często nawiązujące do powszechnie używanych wyrażeń nie będzie spełniało tego wymogu. Warto zauważyć, że takie frazy są bardzo często rejestrowane jako znaki towarowe np. „Ich stu ona jedna”,

${ }^{34}$ SA zmienił wyrok SO, ale tylko w takim zakresie, że odstapił od obciążania powoda kosztami procesu na rzecz strony pozwanej.

${ }^{35}$ Wyrok SA w Warszawie, I ACa 1216/12, www.orzeczenia.ms.gov.pl, Legalis, nr 1048964

${ }^{36}$ Znak towarowy zarejestrowany w UPRP, nr prawa wyłącznego 105205. 
„Wszystko albo nic”37. „Twój Problem Nasza Głowa”38, „Mikołajów masa dla ciebie kasa”39, „GORĄCY SMAK MEKSYKU”40.

\section{Utwory słowno-graficzne}

Chyba najbardziej popularnymi znakami w obrocie sa znaki słowno-graficzne, które łączą w sobie elementy słowne (wyrazy, frazy, wyrażenia) z elementami graficznymi (grafika, rysunkiem, specjalna czcionka, kolorem). Także w przypadku takiego rodzaju znaków może powstać pytanie, czy można je kwalifikować jako utwór i czy w konsekwencji może przysługiwać im ochrona na podstawie pr.aut. Sądy w kilku orzeczeniach wypowiedziały się także na ten temat.

Pierwsze z orzeczeń (SN z 25 października 1988 r. ${ }^{41}$ ) dotyczyło znaku towarowego słowno-graficznego New-Man (zob. poniżej, rys. 6). W sprawie tej powód od 1968 r. używał jako znak towarowy logogryfu „NEW MAN”. Posiadał też prawa autorskie do niego. Powód chciał zgłosić swój znak towarowy do rejestracji w polskim Urzędzie Patentowym 7 maja 1984 r. Urząd Patentowy RP wskazał jednak, że podobny znak towarowy słowno-graficzny „NEW WAVE” został już zarejestrowany na rzecz innego podmiotu z pierwszeństwem od 30 kwietnia $1984 \mathrm{r}$. Warto podkreślić, że tytułem do ochrony prawnoautorskiej obu znaków nie było ich brzmienie, ale oryginalne liternictwo znaku powoda, które naśladował w swoim znaku pozwany ${ }^{42}$.

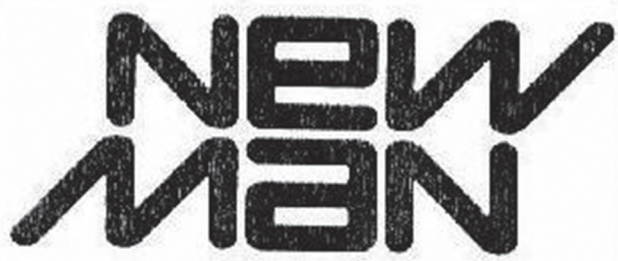

Rysunek 6. Zarejestrowany znak słowno-graficzny, nr prawa wyłącznego 73943

W tym stanie rzeczy powód wystapił do sądu, żądając uznania, że dokonana rejestracja narusza prawa uczciwej konkurencji. Sąd pierwszej instancji uznał, że pozwany dopuścił się aktów nieuczciwej konkurencji i naruszył prawa autorskie powoda do jego znaku towarowego. Wyjaśnić należy, że SN uchylił orzeczenie sądu pierwszej instancji ze względu na braki natury procesowej, jednakże wyraźnie przyznał, że znakom słowno-graficznym może przysługi-

${ }^{37}$ Znak towarowy zarejestrowany w UPRP, nr prawa wyłącznego 125206.

38 Znak towarowy zarejestrowany w UPRP, nr prawa wyłącznego 125221.

${ }^{39}$ Znak towarowy zarejestrowany w UPRP, nr prawa wyłącznego 191876.

${ }^{40}$ Znak towarowy zarejestrowany w UPRP, nr prawa wyłącznego 241047.

${ }^{41}$ Wyrok SN z 25 października 1988 r., II CR 143/88 wraz z komentarzem M. Kępińskiego, „Orzecznictwo Gospodarcze”, nr 3, 1991, poz. 57, s. 34-39.

42 Zob. M. Kępiński, Komentarz do wyroku SN II CR 143/88, s. 38. 
wać ochrona sądowa na podstawie przepisów prawa autorskiego; podkreślił, że „warunkiem udzielenia tej ochrony będzie wykazanie, że znak towarowy "NEW MAN« jest dziełem w rozumieniu prawa autorskiego (przedmiotem ochrony autorskiej)".

Kolejnym orzeczeniem był wyrok SN z 23 czerwca 1989 r. ${ }^{43}$ Sprawa ta dotyczyła sporu o niezarejestrowany znak graficzny „PYRAMID” (zob. poniżej, rys. 7). Powód opatrywał swe towary (zespoły elektroakustyczne) znakiem towarowym słowno-graficznym „PYRAMID”. Także pozwany opatrywał swoje towary (wyroby elektroakustyczne) takim samym znakiem towarowym. W tym stanie rzeczy powód wystapił przeciwko pozwanemu, twierdząc, że to on nabył wszelkie prawa autorskie od twórcy spornego oznaczenia i tym samym miał prawo do wyłącznego posługiwania się znakiem w obrocie. Sąd wojewódzki oddalił powództwo, a rewizję nadzwyczajną do Sądu Najwyższego wniósł powód.

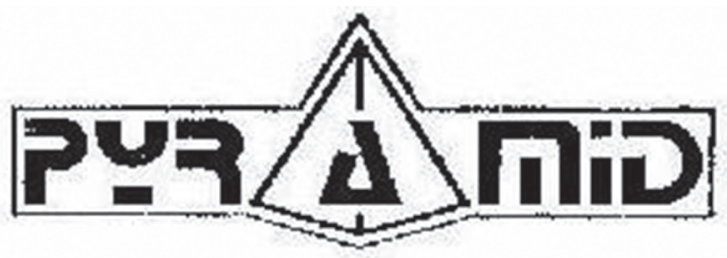

Rysunek 7. Zarejestrowany znak słowno-graficzny, nr prawa wyłącznego $75238^{1}$

Najważniejszy w niniejszej sprawie jest fakt, że Sąd Najwyższy uznał, że nie jest wykluczona kumulatywna ochrona znaków towarowych, gdy spełniaja one wszystkie wymogi przewidziane w przepisach zarówno ustawy o znakach towarowych ${ }^{44}$ (obecnie pr.wł.przem.), jak i w ustawie pr.aut. Wydaje się, że SN stanął na stanowisko, że powód mógłby dochodzić swoich praw z tytułu naruszenia praw autorskich do spornego oznaczenia „PYRAMID”, które mogło być chronione na podstawie przepisów prawa autorskiego. Jednakże powód nie udowodnił kwestii dotyczacych nabycia praw autorskich do tego utworu. W konsekwencji SN uchylił wyrok sądu wojewódzkiego i w celu wyjaśnienia tych wątpliwości przekazał sprawę do ponownego rozpatrzenia.

Następne orzeczenie - Sądu Apelacyjnego w Łodzi z 26 lutego 1998 r. ${ }^{45}$ dotyczyło sporu powstałego w stosunku do znaku towarowego „LADY SABRINA", który miał być umieszczany na etykietach rajstop. Powód przygotował na zlecenie pozwanego kilka projektów wstępnych etykiet dla produktów produkowanych przez pozwanego - rajstop wraz ze znakiem towarowym „LADY SABRINA”. Pozwany wybrał jeden z projektów i przekazał je do drukarni. Powód nie otrzymał jednak wynagrodzenia i wycofał projekty z druku. W tej sytuacji pozwany zmienił projekt etykiet powoda i umieścił je na innych opa-

${ }^{43}$ Wyrok SN z 23 czerwca 1989 r., I CR 236/89, wkładka do „Przeglądu Ustawodawstwa Gospodarczego" 1990, nr 7, pkt 19.

${ }^{44}$ Ustawa z 31 stycznia 1985 r., Dz. U. Nr 5, poz. 17 ze zm.

45 Wyrok SA w Łodzi z 26 lutego 1998 r., I ACa 39/98, OSA 1999, nr 2, poz. 6, s. 22, Legalis, nr 41839 . 
kowaniach. Powód wniósł powództwo do sądu o naruszenie jego autorskich praw majątkowych i osobistych.

Sąd pierwszej instancji i Sąd Apelacyjny rozstrzygnęły, że doszło do naruszenia prawa autorskich osobistych i majątkowych powoda. Tym samym nie ulega wątpliwości, że sądy uznały, że tego rodzaju projektom należy przyznać także ochronę prawnoautorska.

Sąd Najwyższy w jeszcze jednym orzeczeniu (z 6 marca 2002 r.) wypowiedział się na temat znaku słowno-graficznego - dotyczyło ono znaku „SUPER MODEL" ${ }^{46}$. Sąd potwierdził, że znak towarowy może korzystać z kumulowanej ochrony, i wyjaśnił, ,że sporne logo jest dziełem w rozumieniu przepisów ustawy o prawie autorskim”; podkreślił także, że „to powód, który nie jest jego autorem, domagając się zaprzestania używania tego znaku przez pozwanego, powinien wykazać, że służy mu do niego określone prawo majątkowe, wynikajace z przepisów ustawy o prawie autorskim i prawach pokrewnych".

Biorac pod uwagę powyższe orzeczenia sądów, znaki towarowe słowno-graficzne mogą być kwalifikowane jako utwór i moga być chronione na podstawie przepisów pr.aut. Należy jednak pamiętać, że w razie dochodzenia roszczeń w związku z naruszeniem autorskich prawa majątkowych powód będzie musiał wykazać, że przysługuja mu autorskie prawa majątkowe, co - jak wynika z powyższych orzeczeń - może być w niektórych przypadkach trudne do udowodnienia.

\section{PODSUMOWANIE}

Znaki towarowe zarejestrowane i niezarejestrowane mogą być na gruncie prawa polskiego kwalifikowane jako utwory w rozumieniu pr.aut. Jak jednak wynika z powyżej wskazanych orzeczeń, ochrona prawnoautorska jest praktycznie wyłączona w przypadku znaków słownych (zarówno jednowyrazowych, jak i składających się z kilku wyrazów). Wyłączenie tej ochrony nie wynika jednak z tego, że znaki są dobrami własności przemysłowej, ale z faktu, że takie krótkie zwroty nie są w ogóle utworami. Nie spełniają bowiem przesłanki „przejawu działalności twórczej o indywidualnym charakterze”. Jak zauważa słusznie Marcin Trzebiatowski, reglamentowanie autorskoprawnej ochrony utworów słownych jest raczej wyjątkiem niż zasada ${ }^{47}$. Stanowisko takie zasługuje na aprobatę. Można by nawet postulować, że ochrona prawnoautorska dla znaków towarowych powinna zostać wyłączona. Chodzi o to, by prawo autorskie zostało „odciążone”. Twierdzenie takie nie znajduje jednak oparcia ani w przepisach prawa, ani wśród przedstawicieli doktryny.

Podobnie jest też z sądami, które są skłonne kwalifikować słowno-graficzne znaki towarowe jako utwory i przyznawać im ochronę prawnoautorską. Nie ulega wątpliwości, że podobnych rozstrzygnięć można się spodziewać w przy-

${ }^{46}$ Wyrok SN z 6 marca 2002 r., V CKN 830/00, Legalis, nr 140387.

${ }^{47}$ M. Trzebiatowski, Autorskoprawny status znaku towarowego (przeglad doktryny), „Monitor Prawniczy" 2011, nr 5, s. 250. 
padku innych znaków towarowych, np. plastycznych (np. flakon perfum) czy muzycznych.

Powszechnie przyjmuje się, że znaki towarowe mogą korzystać z tzw. ochrony kumulowanej. Kumulacja ochrony znaków towarowych może wystapić także z innymi dobrami własności przemysłowej, a w szczególności z wzorami przemysłowymi ${ }^{48}$. Znaki towarowe mogą być także chronione na podstawie ustawy o zwalczaniu nieuczciwej konkurencji ${ }^{49}$. Trzeba oczywiście pamiętać, że zakres praw majątkowych do utworu i praw ochronnych na znak towarowy różnią się od siebie ${ }^{50}$.

Niewątpliwie więc problematyka znaków towarowych jest skomplikowana. Wytyczenie granic ochrony poszczególnych dóbr niematerialnych nie jest proste i w praktyce prowadzi do licznych niejasności i sporów. Należy też podkreślić, że wielu sporów dotyczących znaków towarowych/utworów udałoby się uniknąć, gdyby zainteresowane strony zawierały odpowiednie umowy, jasno i precyzyjnie określające, komu i w jakim zakresie przysługują prawa do danego znaku towarowego/utworu.

dr Jakub Keqiński

Uniwersytet im. Adama Mickiewicza w Poznaniu

jakep@amu.edu.pl

\section{CAN A TRADEMARK BE COPYRIGHT PROTECTED?}

\section{Sum mary}

Trademarks may be subject to copyright protection as long they fulfil the requirements of copyright law. Consequently, a practical question arises whether a trademark, being a single word or a simple sequence of words, may be protected under copyright law. Such protection entails serious consequences because copyright granted to a creator of a work may later become an obstacle when it comes to the registration of a trademark. It may also constitute grounds for invalidating a trademark already registered. The author examines views of the doctrine and judicial decisions of common courts in the above matters.

${ }^{48}$ Zob. M. Poźniak-Niedzielska, Ochrona kumulatywna wzorów przemysłowych w prawie polskim, w: System, t. 14B, s. 341-343; J. Kępiński, Wzór przemysłowy i jego ochrona w prawie polskim i wspólnotowym, Warszawa 2010, s. 295-315; J. Sitko, Kumulacja i kolizja prawa do znaku towarowego $i$ wzoru przemysłowego $w$ prawie krajowym $i$ unijnym, „Zeszyty Naukowe Uniwersytetu Jagiellońskiego. Prace z Prawa Własności Intelektualnej” 2012, z. 116, s. 86-113.

49 Ustawa z 16 kwietnia 1993 r., t.jedn.: Dz. U. 2003, Nr 153, poz. 1503.

50 Zob. M. Kępiński, Prawo autorskie..., s. 161-162. 
